\title{
Kendala Calon Pendidik Dalam Membuat Soal Pilihan Ganda Higher Order Thinking (Hot)
}

\section{Joan Hesti Gita Purwasih}

Prodi Pendidikan Sosiologi, Fakultas Ilmu Sosial, Universitas Negeri Malang, Malang, 65145.

joan.hesti.fis@um.ac.id

Diterima: $07 / 04 / 2020$

Direview: $23 / 04 / 2020$

Diterbitkan: 30/07/2020

Hak Cipta @ 2019 oleh Penulis (dkk) dan Jurnal Sosial Humaniora (JSH)

*This work is licensed under the Creative

Commons Attribution International License (CC BY 4.0).

http://creativecommons.org/licenses/by/4.0/ (c) (†) Open Access

\begin{abstract}
Subject Area : Education (Pendidikan)
Abstract

This study shows the causes of sociology education students' difficulties in making higher order thinking (HOT) tests. The method applied is the mix method through FGD data collection and questionnaires. The results showed that it was difficult for students to make HOT questions because 1) it was challenging to create stimulus questions, 2) lack of understanding of sociology material, 3) lack of mastery of Bloom's taxonomy application, 4) insufficient learning time, and 5) lecturer explanations were not good. Therefore, recommendations for effective learning improvement are needed, including using the principle of discovery learning.
\end{abstract}

Keywords: mahasiswa; Higher Order Thinking; PISA; Bloom.

\section{Pendahuluan}

Pendidikan di era disruspsi menghadapi tantangan cukup besar. Seiring kemajuan ilmu pengetahuan dan teknologi, sumber daya manusia di setiap negara dituntut memiliki kecakapan yang memadai untuk siap menghadapi persaingan global. Sayangnya, tantangan tersebut tampaknya belum cukup siap dihadapi Indonesia. Kondisi ini dibuktikan dengan adanya pasang surut hasil evaluasi yang dirilis PISA (Programme for International Student Assessment). PISA sendiri merupakan bagian dari program yang diselenggarakan oleh OECD (Organisation for Economic Co- operation and Development).

Tabel 1. Hasil PISA Indonesia

\begin{tabular}{|l|l|l|l|}
\hline \multirow{2}{*}{ Kompetensi } & \multicolumn{2}{l|}{ Rata-Rata Skor PISA (Tahun) } \\
\cline { 2 - 4 } & 2012 & 2015 & 2018 \\
\hline Membaca & 382,3 & 386 & 358 \\
\hline Matematika & 375 & 386 & 379 \\
\hline Sains & 382 & 403 & 396 \\
\hline
\end{tabular}

Bagi sebagian masyarakat, PISA mungkin tidak sepenuhnya dipahami sangat penting bagi pendidikan. Meskipun demikian, penilaian internasional ini patut menjadi cermin yang harus dipertimbangkan untuk menilai suatu keberhasilan pendidikan. Soal-soal yang digunakan dalam tes tersebut mengandung kemampuan 
berpikir tingkat tinggi atau higher order thinking skill (HOTS) siswa. Kemampuan ini sangat penting karena dengan kemampuan berpikir tingkat tinggi siswa dapat belajar menjadi seseorang yang mampu memecahkan masalah produktif (Pratama \& Pramesti, 2018).

Berkaca dari hasil PISA, kondisi tersebut kemudian mendapat respons keras dari pemerintah. Arah kebijakan pendidikan Indonesia pun sedikit banyak dipengaruhi oleh hasil PISA (I. Pratiwi, 2019) Kenyataannya, kebijakan kurikulum 2006 yang kini diganti dengan kurikulum 2013 juga dipengaruhi oleh hasil PISA. Kondisi ini dapat diamati pada bagian pendahuluan yang dinyatakan dalam faktor eksternal PERMENDIKBUD No. 69 Tahun 2016 (Kemendikbud, 2013). Menjelang akhir tahun 2019 Nadim Makarim selaku menteri Pendidikan dan Kebudayaan melakukan trobosan arah kebijakan pendidikan yang mengusung tema "Merdeka Belajar". Salah satu sorotan tajam terkait dapat dilihat pada kebijakan UN yang nantinya diganti dengan model evaluasi pengukuran kemampuan minimum yang terdiri atas literasi, numerik, dan budipekerti (pengelola web kemdikbud, 2019). Ketiganya pada prinsipnya dilakukan untuk mengukur kemampuan berpikir tingkat tinggi siswa.

Menjelang kebijakan tersebut, muncul tandatanya besar yang harus segera dipecahkan. Akankah sumber daya calon guru masa depan Indonesia mampu menghadapi kesempatan dan tantangan baru tersebut? Sayangnya, masih banyak guru yang belum bisa memiliki keterampilan membuat soal HOT dengan baik (Rahayu, Purnomo, \& Sukidin, 2014), (Awaliyah, 2018), (Siswoyo \& Sunaryo, 2017). Dinamika inilah yang harus ditangkap oleh penyelenggara pendidikan tinggi, khususnya yang bergerak di bidang pendidikan. Sebelumnya, penelitian terdahulu lebih fokus pada guru yang sudah memiliki pengalaman mengajar. Sementara itu, mahasiswa calon pendidik kurang mendapat sorotan. Padahal merekalah merupakan agen pendidik masa depan. Oleh karena itu, penelitian ini berupaya merefleksikan penyebab rendahnya penguasaan mahasiswa dalam menguasai keterampilan pembuatan soal HOT. Adapun contoh kasus yang diangkat ialah mahasiswa Jurusan Sosiologi UM yang menempuh matakuliah Evaluasi Pembelajaran di tahun 2019.

Secara umum, kemampuan membuat soal HOT merupakan tanggung jawab capaian yang dibebankan lebih pada matakuliah Evaluasi Pembelajaran. Matakuliah ini memuat garis besar materi mengenai cara mengukur ketercapaian pembelajaran baik secara tes maupun non-tes (Arifin, 2012). Artinya, materi mengenai kemampuan berpikir tingkat tinggi (HOT) hingga implementasi praktik pembuatannya seharusnya juga diberikan dalam mata kuliah tersebut. Kenyataannya mahasiswa cukup sulit mengembangkan keterampilan membuat soal HOT, khususnya soal dalam bentuk pilihan ganda yang menstimulus kemampuan berpikir tingkat tinggi. Pilihan ganda pada umumnya banyak digunakan sebagai jenis tes di sekolah karena memiliki banyak keunggulan di antaranya stimulus serta pilihan dapat bervariasi, mudah dikerjakan, dan bersifat objektif. Selain itu, pilihan ganda diterapkan dalam berbagai jenis tes misalnya UN, USBN, dan ujian masuk perguruan tinggi. Selama mengajar matakuliah Evaluasi Pembelajaran di Program Studi Pendidikan Sosiologi UM terdapat $80 \%$ mahasiswa yang sulit merumuskan soal dengan kategori kemampuan berpikir tingkat tinggi. Kondisi ini tampak saat mahasiswa memaparkan dan mendiskusikan contoh-contoh soal yang mereka buat di kelas. Selain itu, berdasarkan hasil survei mahasiswa sendiri merasa belum bisa terampil membuat soal HOT. Kondisi tersebut ditunjukkan melalui diagram berikut. 
Gambar 1. Mahasiswa merasa tidak terampil membuat soal HOT

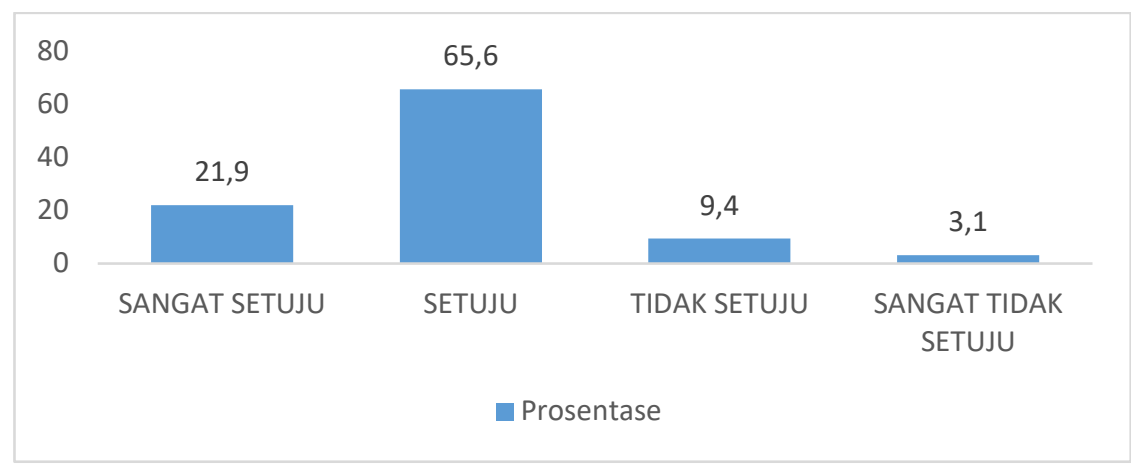

Sumber: Survei peneliti (2020)

Data menunjukkan prosentase mahasiswa yang menyatakan tidak terampil membuat soal HOT sebesar 21.9\% (sangat setuju) dan 65,5\% (setuju). Hal ini memengaruhi persepsi mahasiswa karena menurut mereka menjadi seorang guru merupakan pekerjaan yang sulit. Selain itu, mereka menilai bahwa diri mereka tidak siap menjadi seorang guru. Kondisi tersebut peneliti tunjukkan melalui data survei berikut.

Gambar 2. Mahasiswa merasa guru merupakan pekerjaan yang sulit

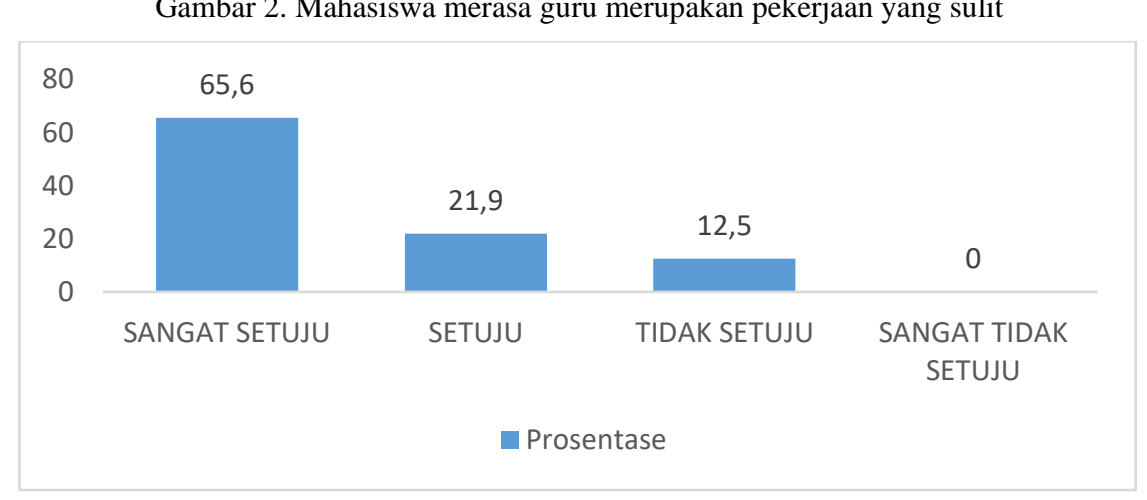

Sumber: Survei peneliti (2020)

Gambar 3. Mahasiswa merasa tidak siap menjadi guru

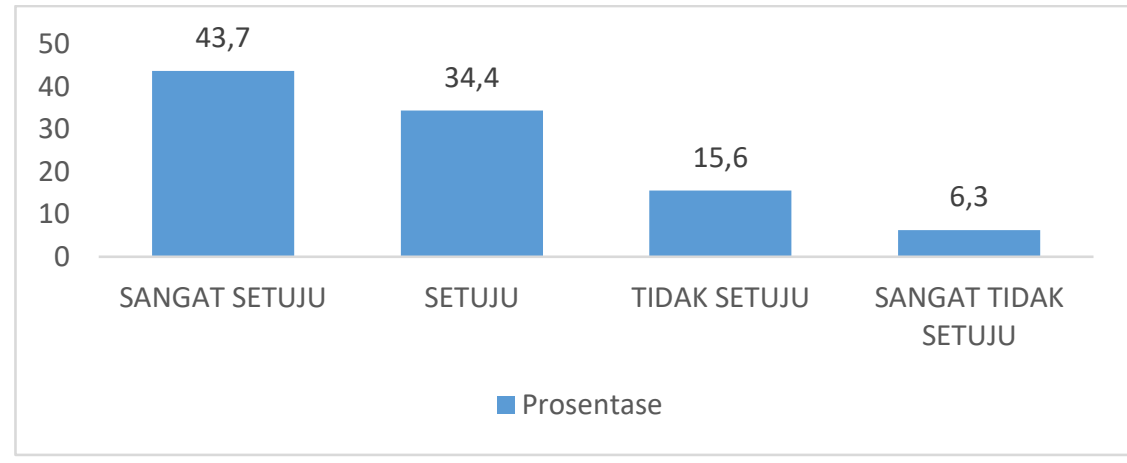

Sumber: Survei peneliti (2020) 
Oleh karena itu, peneliti melakukan penelitian untuk menggali sebab-sebab utama kendala penyerapan materi pembuatan soal HOT dengan jenis tes pilihan ganda bagi mahasiswa. Dengan demikian, upaya peningkatan kualitas pembelajaran dan sumber daya mahasiswa pada matakuliah Evaluasi Pembelajaran dapat ditingkatkan dengan baik.

\section{Tinjauan Pustaka}

Ada tiga prinsip utama dalam membuat soal HOT sebagai berikut. (1) Use introductory material or allow access to resource material, (2) use novel material, dan (3) attend separately to cognitive complexity and difficulty (Brookhart, 2010). Ketiga prinsip dasar inilah yang harus dipahami mahasiswa ketika hendak membuat soal HOT. Akan tetapi, ketiga prinsip tersebut saja tidak cukup harus ada peroses lebih jauh, yaitu pengaplikasikan pengetahuan lagi dalam wujud praktik/keterampilan dalam menyusun soal itu sendiri. Artinya, peroses pembelajaran yang dialami ini menjadi kunci utama keberhasilan pengolahan pengetahuan yang sifatnya dasar bertransformasi lenjadi lebih kompleks. Proses tersebut menurut Bruner terjadi secara bertahap dari proses terencana yang dilaksanakan dari tahap sederhana hingga kompleks. Tiga tahapan belajar Bruner di antaranya pemahaman informasi, pengolahan informasi, dan evaluasi (Bruner, 1999). Terkait dengan konsep tersebut, maka model pembelajaran seperti discovery learning sangat tepat diimplementasikan dengan pembelajaran. Tentu saja pada kasus ini mahasiswa sangat dimungkinkan bisa menguasai materi yang sulit jika pembelajaran yang diterapkan menggunakan model yang tepat seperti discovery learning (Nurrohmi, Utaya, \& Utomo, 2017; Afandi, 2013).

\section{Metode Penelitian}

Penelitian ini menerapkan jenis penelitian mix method yang dilakukan melalui tahap kualitatif kuantitatif (Creswell, 2013). Peneliti melakukan penggalian data kualitatif dengan melakukan FGD pada sepuluh mahasiswa yang diwakili oleh dua kelas mata kuliah Evaluasi Pembelajaran pada program studi Pendidikan Sosiologi. Hasil data kualitatif tersebut merupakan pemetaan berbagai kendala yang dirasakan mahasiswa ketika dihadapkan dengan materi pembuatan soal HOT pada mata kuliah tersebut. Setelah melakukan analisis data dengan mereduksi, mendisplay, dan menarik kesimpulan, diperoleh hasil pemetaan kualitatif. Ini menjadi indikator bagi peneliti untuk mengembangkan angket sebagai instrumen survei pada tahap kuantitatif. Data kualitatif diperkuat oleh data kuantitatif dengan menghitung tendensi sentral. Adapun persepsi siswa terhadap kendala pemahaman materi pembuatan soal HOT diukur menggunakan skala Likert dan diisi oleh 32 mahasiswa Jurusan Sosiologi yang menempuh matakuliah Evaluasi Pembelajaran di tahun 2019 semester Gasal (kuota sampling). Hasilnya, disajikan dalam bentuk prosentase persepsi keseluruhan mahasiswa yang menjadi populasi dalam kelas Evaluasi Pembelajaran. Melalui kedua metode tersebut, peneliti dapat memperoleh data yang lebih kaya, yaitu tidak hanya mendalam tetapi juga menyeluruh.

\section{Hasil Penelitian dan Pembahasan}

\section{Alasan Mahasiswa Sulit Membuat Soal HOT}


Keterampilan membuat HOT seharusnya diajarkan oleh setiap prodi pendidikan karena berhubungan dengan standar penilaian yang dicanangkan pemerintah. Keterampilan ini memang dibebankan lebih pada matakuliah Evaluasi Pembelajaran, tetapi hal ini juga berkaitan dengan penguasaan matakuliah lain seperti Kajian Kurikulum dan Buku Teks dan Bahasa Indonesia. Soal pada tentu harus berkaitan dengan materi di sekolah, disajikan dengan bahasa yang mudah dipahami, kontekstual, dan mendorong daya analisis tinggi. Hal ini terbukti dari argument-argumen yang dikemukakan mahasiswa selama FGD. Garis besar hasil FGD tersebut dituangkan dalam angket dan dijadikan sebagai indikator yang mewakili persepsi mahasiswa lainnya. Pada akhirnya, peneliti dapat menyajikan data kualitatif yanterkait penyebab mahasiswa sulit membuat soal HOT sebagai berikut.

a. Sulit membuat stimulus dan kalimat soal dengan baik.

Secara umum soal pilihan ganda memiliki anatomi soal yang terdiri atas stimulus, kalimat soal, dan pilihan jawaban (ada pengecoh dan kunci). Selain itu terdapat kaidah-kaidah dalam penulisan soal pilihan ganda yang juga bisa menentukan kualitas soal serta level berpikirnya (Kadir, 2015). Terkait bagian-bagian tersebut, hasil FGD menunjukkan mahasiswa ternyata sulit membuat stimulus soal.

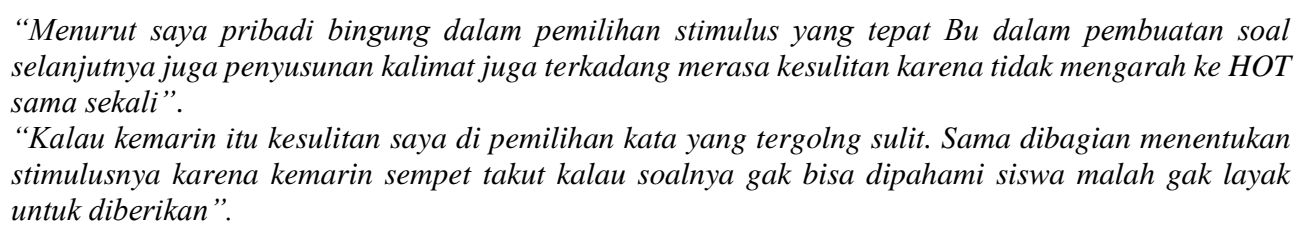

Kondisi ini juga dirasakan oleh mahasiswa lainnya. Berdasarkan hasil angket $28.1 \%$ menyatakan sangat setuju dan 50\% setuju bahwa stimulus dan menyusun kalimat dengan baik tergolong sulit bagi mereka.

Gambar 4. Mahasiswa sulit membuat stimulus dengan baik

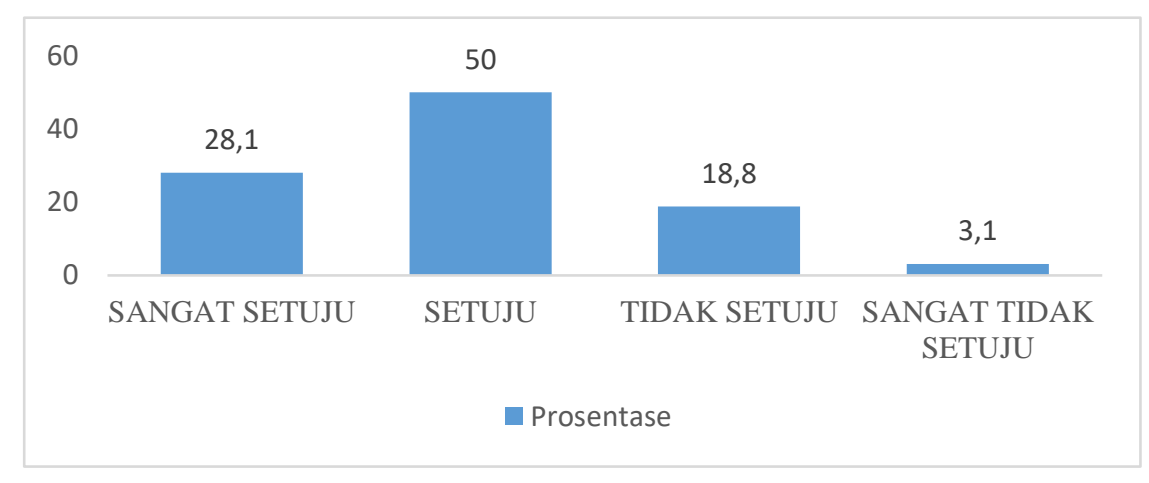

Sumber: Survei peneliti (2020)

b. Tidak menguasai materi sosiologi di SMA.

Perubahan kurikulum tahun 2006 menjadi kurikulum 2013 menyebabkan banyak perubahan pada materi pelajaran sosiologi di jenjang SMA. Kondisi ini dapat diamati pada struktur Kompetensi Inti dan Kompetensi dasar yang tertuang dalam PERMENDIKBUD no 24 Tahun 2016. Perubahan tersebut menyebabkan dampak signifikan bagi materi sosiologi, karena perubahan yang terjadi pun sangat besar. Sementara itu, sumber-sumber yang ada saat ini tidak sepenuhnya memberikan informasi memadai. 
Sebenarnya, mahasiswa sudah dikenalkan mengenai materi-materi yang ada di sekolah melalui mata kuliah Kajian Kurikulum dan Buku Teks Sosiologi. Akan tetapi, kenyataannya mahasiswa juga masih belum cukup memahami materi-matari yang berlaku di sekolah saat ini. Oleh karena itu, mereka kesulitan ketika harus membuat soal yang sesuai dengan materi.

\begin{abstract}
"Saya kesulitan membuat soal dengan tingkat analisis tinggi atau HOT karena ada beberapa faktor sih Bu, seperti yang utama dan pertama mengenai pemahaman dan penguasaan materi-materi belajar Sosiologi. Untuk membuat soal dengan tingkat analisis tinggi, seorang tenaga pendidik harus menguasai materi sehingga soal yang dibuat itu bukan berupa konsep-konsep saja dan jatuhnya akan menghasilkan soal-soal yang sifatnya hanya menghafal".
\end{abstract}

Pernyataan ini diperkuat dengan hasil angket yang menunjukkan 6,4\% (sangat setuju) dan 43,8\% (setuju) bahwa materi sosiologi tidak mereka kuasai sehingga pembuatan soal HOT menjadi sulit dibuat.

Gambar 5. Mahasiswa tidak menguasai materi sosiologi di SMA

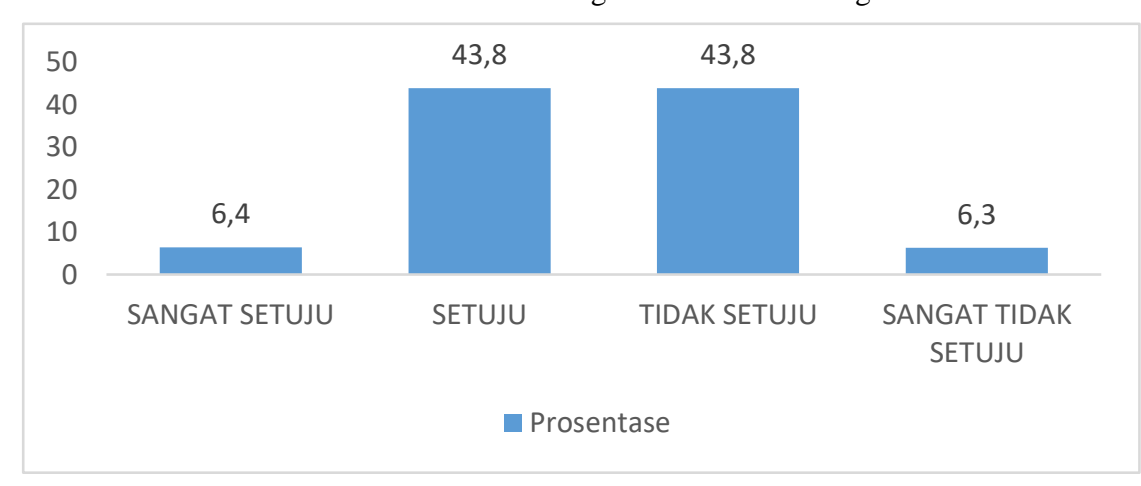

Sumber: Survei peneliti (2020)

c. Kurang menguasai penerapan taksonomi Bloom (yang direvisi Anderson).

Konsep berpikir tingkat tinggi pada umumnya mengacu pada tingkat kognitif yang dipetakan oleh Bloom (kemudian direvisi oleh Anderson). Ada enam tingkatan yang kognitif yaitu mengingat, memahami, menerapkan, menganalisis, mengevaluasi, dan mengkreasi. Tingkatan ini membantu penulis soal memetakan level berpikir tingkat tinggi yang pada umumnya mengacu pada level analisis, evaluasi, dan mengreasi. Akan tetapi, mahasiswa sulit mengaplikasikan soal yang sudah mengacu pada level tersebut karena pemahaman mereka terhadap tingakatan berpikir ini masih belum dikuasai.

\footnotetext{
"Taksonomi yang digunakan kadang bingung Bu sudah ditentukan C4 misalnya ketika besok di periksa lagi bingung karena ada kata taksonomi yang sama dengan lain".

"Sulit menentukan kata" di soalnya yg taksonomi bloom itu bu, Karena kan juga harus sesuai dengan beban soal nya C2 atau C4 dst nya”.
}

Kondisi ini juga diperkuat dengan hasil angket yang menunjukkan bahwa 15,6\% (sangat setuju) dan $68,8 \%$ (setuju) dengan pernyataan bahwa mereka tidak menguasai pengaplikasian taksonomi Bloom yang direvisi oleh Anderson. 
Gambar 6. Mahasiswa tidak menguasai taksonomi Bloom

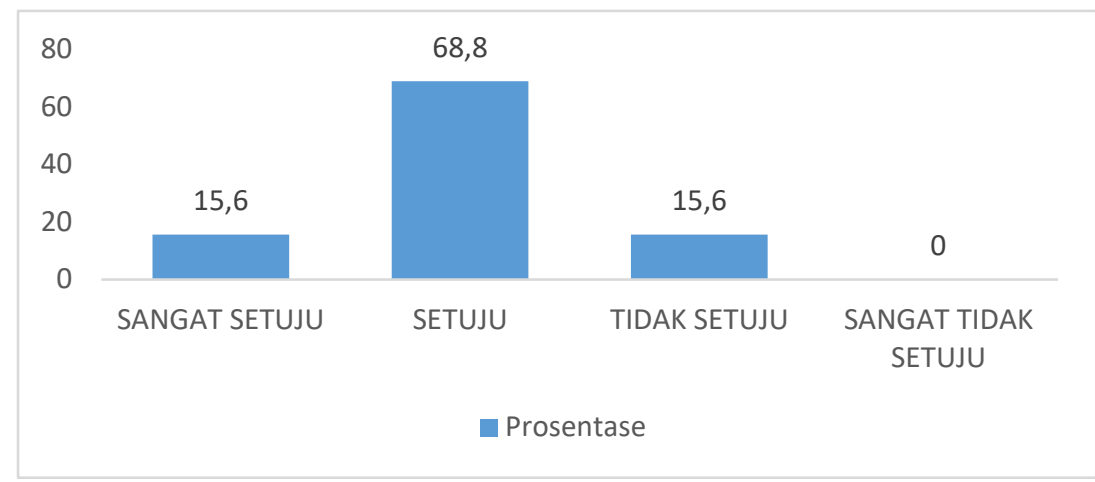

Sumber: Survei peneliti (2020)

Selain faktor penguasaan materi, ketidakmampuan mahasiswa dalam mengembangkan keterampilan juga dipengaruhi oleh faktor pembelajaran di kelas, terutama waktu dan dosen. Pada kondisi ini dosen dinilai kurang bisa memberikan pemahaman yang baik bagi mahasiswa. Sementara itu, materi yang padat membuat materi penulisan soal HOT terbatas, Hal ini diungkapkan melalui hasil FGD dan angket berikut.

d. Waktu yang dibutuhkan di kelas tidak cukup.

Bobot untuk matakuliah evaluasi pembelajaran pada umumnya 3 SKS, artinya ada sekitar 150 menit untuk setiap tatap muka. Adapun dalam rancangan RPS durasi untuk membahas taksonomi Bloom dan penulisan soal disediakan tiga kali tatap muka. Pembagian tersebut diberikan mengingat materi lain dalam matakuliah Evaluasi Pembelajaran cukup banyak. Sementara itu, mahasiswa sangat ingin ada pengulasan materi-materi terkait dengan pembuatan soal.

"Waktu kami untuk belajar membedah kerangka soal itu bu yang menurut saya perlu ditambahi dan lebih di spesifikan lagi. Menurut saya mungkin alangkah lebih baik kita belajar dari membedah kerangka soal ujian nasional atau ujian sekolah yang sudah memiliki kerangka soal yang ideal"

Data kuantitatif menunjukkan bahwa 40\% (sangat setuju) dan 30\% (setuju) bahwa waktu yang dibutuhkan untuk pembuatan soal HOT sangat kurang.

Gambar 7. Waktu belajar di kelas tidak cukup

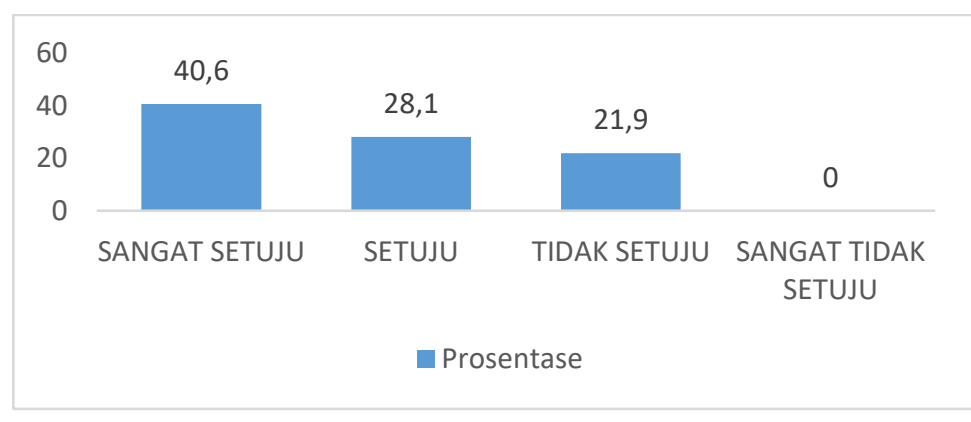

Sumber: Survei peneliti (2020)

e. Dosen kurang bisa memberi penjelasan dengan baik.

Penjelasan mengenai proses dan prosedur pembuatan soal dalam pembelajaran cukup sulit disampaikan dengan baik oleh dosen. Proses dalam pembuatan soal serta pemberian pemahaman yang menunjukkan level soal HOT belum dijelaskan dengan baik pada mahasiswa. 
"Dosen kurang menjelaskan langkah-langkah atau step by step yang benar dalam pembuatan soal hinggga tahap evaluasi nya. Sehingga soal yang dibuat terkesan asal-asalan Bu, karena tidak tahu langkahnya yang benar seperti apa".

Data kuantitatif menunjukkan dosen kurang menjelaskan taksonomi Bloom dengan baik dengan prosentase $6,3 \%$ (sangat setuju) dan 25\% (setuju). Sementara itu, langkah-langkah pembuatan soal HOT dinilai tidak memuaskan sebesar 10\% (sangat setuju) dan 10\% (setuju).

Gambar 8. Dosen kurang mendalam menjelaskan taksonomi Bloom

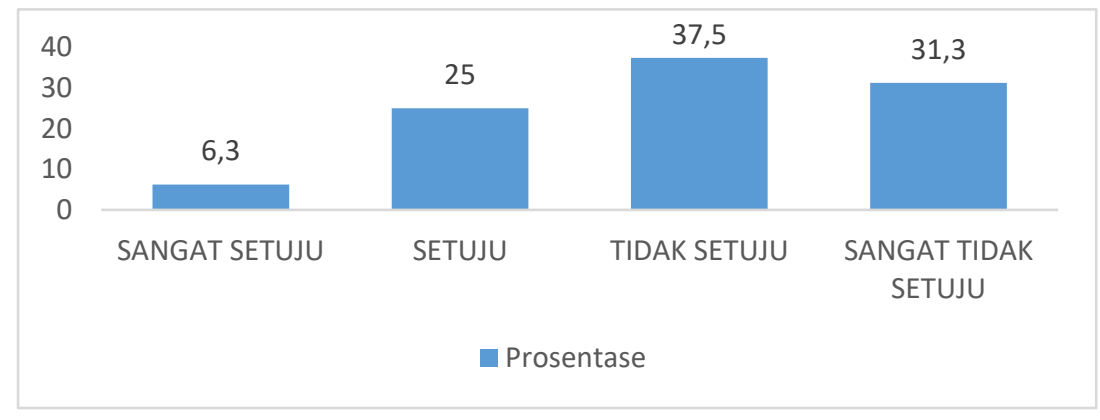

Sumber: Survei peneliti (2020)

Gambar 9. Dosen kurang mendalam menjelaskan langkah-langkah membuat soal HOT

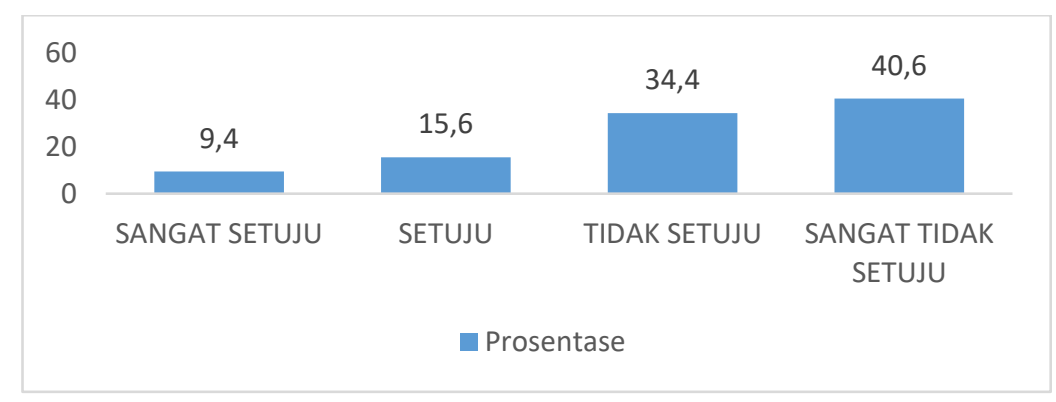

Sumber: Survei peneliti (2020)

\section{Proses Pembelajaran yang Diharapkan Mahasiswa}

Selain menggali penyebab kendala dalam membuat soal HOT, hasil FGD juga menggali persepsi mahasiswa mengenai pembelajaran yang efektif menurut persepsi diri mereka sendiri. Mahasiswa mengharapkan proses pembelajaran dalam materi pembuatan soal HOT perlu disertai dengan beberpa upaya, di antaranya sebagai berikut.

a. Perlu adanya pengulasan garis besar materi sosiologi untuk SMA.

b. Mendalami konsep dimensi kognitif Bloom

c. Penjelasan langkah-langkah membuat soal secara sistematis.

d. Penyediaan sumber yang bisa diakses untuk bisa belajar mandiri

e. Praktik yang memadai dan waktu yang cukup.

\section{Rekomendasi Perkuliahan Kedepan}

Berdasarkan pemaparan data sebelumnya, peneliti melakukan refleksi dan analisis untuk melakukan perbaikan perkuliahan kedepan. Pertama, pembelajaran/perkuliahan ternyata tidak bisa berjalan dengan baik jika dosen memikirkan desain perkuliahannya sendiri. Selama ini perkuliahan sering dinilai sebagai proses tunggal yang hanya boleh dirancang oleh dosen. Evaluasi perkuliahan seperti ini merupakan ruang/pendapat 
bagi mahasiswa yang juga harus diperhatikan. Melalui penelitian sederhana seperti ini perbaikan kualitas pembelajaran dapat dirumuskan tidak lagi dalam tataran subjektif, tetapi objektif. Kedua, sebagai pengajar, dosen tentu memiliki kekurangan atau kelemahan di beberapa hal. Kondisi ini terbukti dengan adanya paparan data yang menunjukkan masih terdapat kelemahan dalam menjelaskan langkah pembuatan soal dan taksonomi Bloom. Oleh karena itu, kerjasama dengan rekan sejawat dalam mengembangkan materi dan metode penyampaian materi dapat dioptimalkan untuk meminimalkan masalah tersebut. Misalnya, dosen melakukan kolaborasi dengan teman sejawat merancang pembelajaran yang efektif melalui lesson study. Lesson study sendiri merupakan cara peningkatan kualitas pembelajaran yang dilakukan melalui tahapan plan, do, dan see. Artinya, melalui proses tersebut, privatisasi kelas mulai diubah menjadi ruang terbuka yang mampu menerima segala masukan (Purwasih \& Perguna, 2018). Ketiga, sumber belajar yang spesifik nuntuk membahas materi ini sangat dibutuhkan, misalnya modul. Modul merupakan salah satu sumber belajar yang efektif dan bermanfaat bagi mahasiswa kedepan (P. H. Pratiwi, 2017). Meskipun demikian, sumber yang diintegrasikan dengan pemanfaatan teknologi dan media pembelajaran berbasis online juga dapat dimanfaatkan agar mahasiswa dapat belajar mandiri. Mereka dapat belajar kapanpun dan dimanapun untuk memperdalam materi yang belum mereka pahami. Bahkan data survei menunjukkan 29\% (sangat setuju) dan 51,6\% (setuju) bahwa pemanfaatan sumber belajar berbasis elektronik/online dapat menunjang proses belajar mandiri mereka. Berdasarkan pertimbangan tersebut maka peneliti merekomendasikan perbaikan kualitas pembelajaran sebagai berikut.

Bagan 1. Saran desain perbaikan pembelajaran

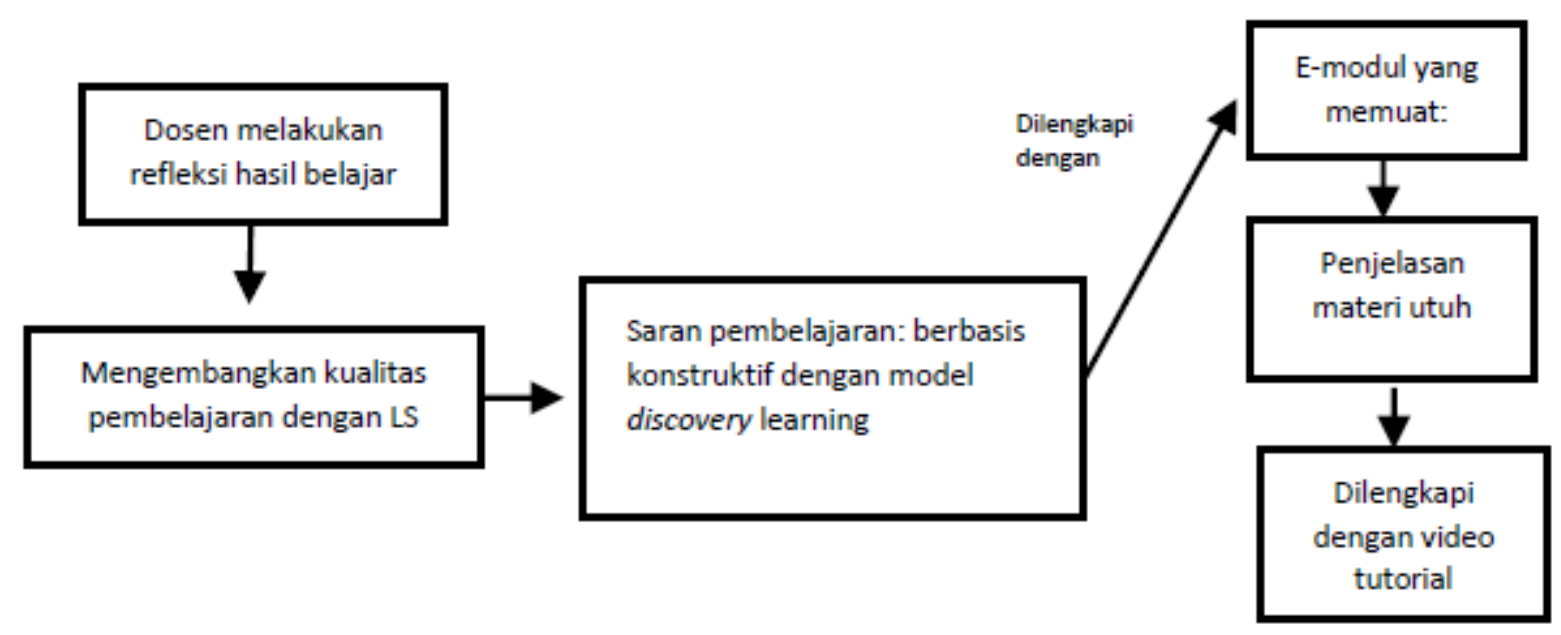

Sumber: Peneliti (2020)

Peneliti merekomendasikan perbaikan kualitas perkuliahan/pembelajaran dengan desain seperti pada bagan 1. Penekanan pada pentingnya proses menerima, mengolah, dan mempraktikkan pengetahuan dapat diimplementasikan melalui model discovery learning. Akan tetapi, model saja tidak cukup sehingga perlu adanya penguatan dengan dosen menyediakan media yang memuat langkah-langkah aktivitas serta garis besar materi memadai, yaitu melalui e-modul. Dengan demikian, waktu belajar yang tidak terakomodasi melalui tatap muka dapat diatasi dengan media tersebut. Pembuatan media ini dapat dikerjakan secara kolaboratif, sehingga kekurangan yang ada dalam diri dosen dapat dikuatkan dengan kemampuan yang dimiliki dosen 
lainnya. Misalnya, dalam menyajikan materi, validitas isi, serta keterlibatan dalam video tutorial tidak hanya dilakukan oleh dosen pengampu yang bertanggung jawab atas mata kuliah tersebut saja, tetapi tim Kelompok Bidang Keahlian terkait.

Desain ini akan peneliti kembangkan dalam penelitian peningkatan kualitas pembelajaran selanjutnya sekaligus penelitian lanjutan yang akan dikembangkan selanjutnya. Harapannya, melalui upaya ini dosen tidak hanya berpikir untuk meningkatan kualitas pembelajaran, tetapi menghasikan penelitian, serta karya yang dapat dimanfaatkan untuk berbagai pihak terkait.

\section{Kesimpulan}

Mahasiswa program studi pendidikan merupakan calon pendidik masa depan sehingga keterampilan mereka harus dipersipakan dengan baik. Tantangan pendidikan saat ini menuntut adanya peningkatan kualitas pembelajaran dan model penilaian yang mengarah pada kemampuan berpikir tingkat tinggi (HOT). Oleh karena itu, perbaikan pembelajaran dalam matakuliah Evaluasi Pembelajaran berlu ditingkatkan. Meminjam pemikiran Bruner, mahasiswa seharusnya diajak merefleksikan kembali dasar-dasar materi yang terkait dengan kompetensi ini. Selanjutnya, penjelasan dan fasilitasi media yang memberikan penjelasan terperinci dan belajar mandiri diberikan untuk memantapkan pemahaman mereka. Barulah praktik-praktik pendalaman dilakukan untuk mengasah kemampuan mereka dalam membuat soal HOT.

\section{Daftar Pustaka}

Afandi. (2013). Pembelajaran Biologi Menggunakan Pendekatan Metakognitif melalui Model Reciprocal Taching dan Problem Based Learning Ditinjau dari Kemandirian Belajar dan Kemampuan Berpikir Kritis Mahasiswa. Jurnal Pendidikan Matematika Dan IPA. https://doi.org/10.26418/jpmipa.v2i2.2182

Arifin, Z. (2012). Evaluasi pembelajaran. Bandung: Remaja Rosdakarya. https://doi.org/979-692-956-2

Awaliyah, S. (2018). Penyusunan soal hots bagi guru ppkn dan ips sekolah menengah pertama. Jurnal Praksis Dan Dedikasi Sosial.

Brookhart, S. M. (2010). How to Assess Higher-Order Thinking Skills in Your Slassroomin Your Classroom. Assess Thinking Higher-Order Skills. Virginia USA: ASCD.

Bruner, J. S. (1999). The Process of Education. USA: Harvard University Press.

Creswell, J. W. (2013). Educational Research: Planning, Conducting, and Evaluating Quantitative and Qualitative Research. Journal of Chemical Information and Modeling. https://doi.org/10.1017/CBO9781107415324.004

Kadir, A. (2015). MENYUSUN DAN MENGANALISIS TES HASIL BELAJAR. Jurnal Al-Ta'dib. https://doi.org/http://dx.doi.org/10.31332/atdb.v8i2.411

Kemendikbud. Peraturan Menteri Pendidikan Pendidikan dan Kebudayaan Republik Indonesia Nomor 69 Tahun 2013 Tentang Kerangka Dasar dan Struktur Kurikulum Sekolah Menengah Atas/Madrasah Aliyah (2013). Indonesia. Retrieved from https://biologi.fkip.uns.ac.id/wp-content/uploads/2013/08/PDK-201369-Kerangka-Dasar-Kurikulum-Kompetensi-SMA.pdf 
Nurrohmi, Y., Utaya, S., \& Utomo, D. H. (2017). Pengaruh Model Pembelajaran Discovery Learning Terhadap Kemampuan Berpikir Kritis Mahasiswa. Jurnal Pendidikan.

OECD (2019). (2019a). Mathematics performance (PISA). https://doi.org/10.1787/79913c69-en

OECD (2019). (2019b). Reading performance (PISA) (indicator). https://doi.org/10.1787/79913c69-en

OECD (2019). (2019c). Science performance (PISA). https://doi.org/10.1787/91952204-en

pengelola web kemdikbud. (2019). Mendikbud Tetapkan Empat Pokok Kebijakan Pendidikan "Merdeka Belajar." Retrieved December 26, 2019, from https://www.kemdikbud.go.id/main/blog/2019/12/mendikbud-tetapkan-empat-pokok-kebijakanpendidikan-merdeka-belajar

Pratama, R. R., \& Pramesti, R. A. (2018). THE IMPORTANCE OF STIM-HOTS AND CRITICAL THINKING SKILL IN DISRUPTION ERA. Social, Humanities, and Educational Studies (SHEs): Conference Series. https://doi.org/10.20961/shes.v1i1.24304

Pratiwi, I. (2019). EFEK PROGRAM PISA TERHADAP KURIKULUM DI INDONESIA. Jurnal Pendidikan Dan Kebudayaan. https://doi.org/10.24832/jpnk.v4i1.1157

Pratiwi, P. H. (2017). PENGEMBANGAN MODUL MATA KULIAH PENILAIAN PEMBELAJARAN SOSIOLOGI BERORIENTASI HOTS (HIGHER ORDER THINKING SKILLS). Jurnal Cakrawala Pendidikan. https://doi.org/10.21831/cp.v36i2.13123

Purwasih, J. H. G., \& Perguna, L. A. (2018). MENGENALKAN LESSON STUDY MELALUI PELATIHAN GURU DI LINGKUNGAN MADRASAH ALIYAH KABUPATEN MALANG. Jurnal Praksis Dan Dedikasi Sosial. https://doi.org/10.17977/um032v0i0p80-86

Rahayu, T. D., Purnomo, B. H., \& Sukidin, S. (2014). Analisis Tingkat Kesukaran Dan Daya Beda Pada Soal Ujian Tengah Semester Ganjil Bentuk Pilihan Ganda Mata Pelajaran Ekonomi Kelas X Di Sma Negeri 5 Jember Tahun Ajaran 2012-2013. Edukasi.

Siswoyo, S., \& Sunaryo, S. (2017). High Order Thinking Skills: Analisis Soal dan Implementasinya dalam Pembelajaran Fisika di Sekolah Menengah Atas. Jurnal Penelitian \& Pengembangan Pendidikan Fisika. https://doi.org/10.21009/1.03102 